\title{
Identification And Efficacy Of Strategies For Teaching Entrepreneurship Education Among Students In Tertiary Institutions In Kwara State Nigeria
}

\author{
Nwabufo Ngozi Bibiana, Ph.D \\ Department Of Business And Entrepreneurship Education, \\ Kwara State University, Malete \\ P.M.B 1550, Ilorin, Nigeria
}

\begin{abstract}
The paper examined business educators' perception of the strategies for teaching entrepreneurship education and the efficacy of the strategies in developing entrepreneurial skills among students in tertiary Institutions in Kwara State. Two research questions and two hypotheses guided the study. The population of the study consists of 82 Business educators from all the Tertiary Institutions in Kwara State that offer business education programme. A structured questionnaire was used for data collection. Mean and standard deviation were used to analyze data related to research questions, while t-test statistics was used in testing the two null hypotheses of the study. The study revealed that the identified strategies are used by lecturers in teaching entrepreneurship education, and that majority of these strategies are equally effective in developing entrepreneurial skills among students in tertiary institutions. The two null hypotheses of no significant difference were retained at 0.05 level of significance which therefore indicates that the opinion of male and female business educators do not differ significantly on the strategies of teaching entrepreneurship and the efficacy of the strategies in developing entrepreneurial skills among students in tertiary institutions in Kwara State, Nigeria. It was recommended among others that entrepreneurship lecturers should continue to adopt the identified strategies in the teaching and learning of entrepreneurship education, since they are highly effective in inculcating entrepreneurial skills among students in tertiary institutions in Kwara State, and also that curriculum planners should build in dynamic entrepreneurship skills into the curricular at all fields of study so as to make the curricula at every level of education be geared towards the acquisition of entrepreneurial skills for selfreliance.
\end{abstract}

Keywords: Efficacy, Strategies, Entrepreneurship Education, Entrepreneurial Skills, Tertiary Institutions.

\section{INTRODUCTION}

The issue of empowering the Nigeria graduates through entrepreneurship education has taken the center stage of development discourse in Nigeria, especially in the present face of economic crisis and increase in the level of graduates' unemployment scenario plaguing the present Nigeria society. According to Onyesom and Uwaifo, (2013), securing jobs after graduation in the early years in Nigeria after Independence was not a difficult task. The same authors observed that then, most tertiary institutions' graduates secured jobs in their final years in schools, and in some cases most of the students were given employment letters at the orientation camps, during the National Youth Service Corps (NYSC). So, getting jobs by then was not part of the problems of the youths. Today, the situation is apparently the opposite. The soaring rate of graduate unemployment has become a source of worry to the graduates, their parents, relatives, and of course the government. It has become an economic, political, security and social problems in Nigeria, particularly among the young graduates. 
Entrepreneurship education in Nigeria came up as a means of proffering solution to the unemployment challenges facing the young tertiary school graduates. According to Igbo, (2004), entrepreneurship is seen as the willingness and ability of an individual to seek out investment in an environment and be able to manage the investment successfully based on the identified opportunity. Entrepreneurship therefore is the use of human courage to seek investment opportunities and establish profit oriented enterprises (Jimoh-Kadiri, 2012). According to Atakpa,(2011), Entrepreneurship is all about innovation, creativity and intellectual build-up of innovative ideas. According to Hisrich and Peters, (2002), entrepreneurship is a clear manifestation of effective manipulation of human intelligence as demonstrated in creative performance. Entrepreneurship however is the key to personal fulfillment, wealth creation, human capacity, development, and financial empowerment, (Uguowke, 2011). It is therefore seen as the ability to create new ideas, products or services for personal self-reliance and also to meet the needs of the society. This involves the ability to set up business enterprises as different from being employees. This ability should be acquired through the acquisition of skills, ideas and managerial competencies necessary for selfemployment. Entrepreneurship therefore is the process of identifying, developing and bringing a vision to reality.

Entrepreneurship education is relatively young and has experienced considerable growth in just a decade of existence. It is becoming a major topic of debate among curriculum developers. Entrepreneurship education involves teaching and learning of the needed skills and knowledge that equip one to become self-reliant through being an active and successful initiator, manager, innovator and risk manager of business undertakings. Igbo, (2009) supports the above meaning of entrepreneurship education when she says that such education should produce self-reliance, job creators and not job seekers, besides, it equips the individual for creative problem solving and innovation.

In entrepreneurship education, people already in business are retrained to enhance their management, record keeping ability and the profitability of their businesses, while university graduates and school leavers are taught skills and empowered to start their own businesses whereas students who are still in the school are trained to take their fate in to their hands and to become entrepreneurs, even right in the school, (Igbo, 2009). Entrepreneurship education is essential not only to shape the mind set of young people, but also to provide the skills and knowledge that are central to the development of entrepreneurial culture. Entrepreneurship education therefore, provides students and youths with motivation, knowledge and skills essential to launch successful ventures, (Hudson, 2016). The objective of entrepreneurship education is to teach the youths how to see business opportunities, ideas and act on them promptly in order to take advantage over others. This indicates also that it adequately equips students of tertiary institutions with entrepreneurial competencies and skills necessary for successful business venture prior to graduation to enable them contribute their own quota to individual and national economic survival and transformation of a nation, (Oriazowanian, 2013). Therefore, entrepreneurship education is believed to be an important mechanism of economic growth and development. Entrepreneurship education, however, is the process of imparting knowledge and teaching skills to potential entrepreneurs on how to venture into businesses that are relatively small in nature for future advancement of the businesses (Osuala, 2004).

Entrepreneurship education in Nigeria is necessary for the country to become a developed nation. Nigeria has human resources that should be capable of retrieving, processing and utilizing for national resources for the general well-being of her citizens and development of her economy, given, that they have appropriate skills. For these needed skills to be acquired, 
emphases should be directed towards entrepreneurship education which serves as a strategy for transforming the Nigeria economy into one of the twenty largest economies in the world by the year 2020 .

The Nigeria government recognized the need for entrepreneurship education when it directed in 2006, that entrepreneurship education be incorporated into all programmes offered in our tertiary Institutions as a mandatory course for all students. Consequently, the national council on education on its $53^{\text {rd }}$ meeting held in Calabar in Nigeria, same year, also directed the higher education supervisory agencies to commence the production of appropriate training documents and guide for effective and efficient delivery of entrepreneurship education (National Board for Technical Education, 2007)

In response to the directives by the Federal Government and National Council on Education, the National Board for Technical Education, (NBTE), developed and produced curricular and training manuals for use in training students in tertiary institutions for the following courses: Introduction to Entrepreneurship (EED 126), and Entrepreneurship Development (EED 413) These courses are offered as theory and essentially practical in tertiary institutions

The attainment of the objectives of these course offerings will require effective instructional delivery and pedagogy. The preparedness, willingness and the ability of teachers are the major factors that determine the effectiveness of any progamme. If the delivery practice of any course is not effective, it may render the objectives of such course unattainable. The major objective of entrepreneurship is for the graduates of tertiary institutions to acquire adequate understanding of the intricacies of business operations and the skills for entrepreneurship. Successfulness in this area may become unattainable if the course pedagogy and delivery pattern is defective.

As noted by Jimo-Kadiri, (2012), most of the lecturers that teach entrepreneurship education in tertiary institutions in Nigeria have no training in pedagogy. He further affirmed that they do not use appropriate teaching methodology in teaching the students, rather they teach entrepreneurship education most of the time, by lecture method, an old method of teaching whereby the teacher dominates the teaching and learning as an authority without allowing the students to become part and parcel of the teaching and learning process. Usually, course format in entrepreneurship is more informal and tends to focus on 'hands-on' teaching methods. The use of appropriate instructional strategies by different entrepreneurship education lecturers is a sine qua non for knowledge acquisition, retention, assimilation, recall and application by students, (Ezenwafor and Ndinechi'2004). The way a teacher teaches a particular subject has a direct and consequential effect on the student's interest and performance in that subject. Therefore, success in this area of self-employment education is dependent upon the nature of entrepreneurial skills and competencies the Nigerian education is in tune with.

\section{Statement of the Problem:}

Unemployment is particularly acute among young graduates and secondary schools' leavers in Nigeria today. Osuala, (2004), pointed out that graduates and secondary schools' leavers in Nigeria are becoming increasingly unemployed because they lack saleable skills for selfreliance. These saleable skills can only be acquired through entrepreneurship education. However, the methods and techniques of teaching these skills are not clear nor has it been fully documented in terms of the particular methods to be used. The greatest challenge facing entrepreneurship education in Nigeria today is the teaching strategies for inculcating the expected skills to its recipients. Atakpa, (2011), noted that despite the entrepreneurship 
courses offered in Tertiary Institutions, Nigerian graduates in recent times are still wondering about seeking for salaried jobs which are not available. Poor quality teaching therefore, has been identified as a major factor in the ineffectiveness of entrepreneurship education in Nigeria Tertiary Institutions (Jimoh-Kadiri, 2012).

This situation actually necessitated this study. Therefore, there is need to identify and ascertain the effectiveness of the various strategies which lecturers in tertiary institutions in Nigeria employ in teaching entrepreneurship education as mandated by Federal Government of Nigeria, (FGN), in 2006, and National Board for Technical Education (NBTE), in 2007, in Kwara State tertiary institutions, in Nigeria.

\section{Purpose of the study:}

The main purpose of this study was to identify the various strategies used by lecturers in teaching entrepreneurship education in Kwara State tertiary institutions as well as ascertain the effectiveness of the strategies in the development of entrepreneurship among the students:

\section{Research Questions:}

The following research questions were formulated to guide the study:

1. What are the strategies used for teaching entrepreneurship education in tertiary institutions in Kwara State Nigeria

2. How effective are the strategies used for teaching entrepreneurship education in Kwara State tertiary institutions in Nigeria

\section{Research Hypotheses}

The following null hypotheses were formulated and tested at 0.05 level of significance.

$\mathbf{H}_{01}$ : There is no significant difference between the mean responses of male and female business educators on the strategies used for teaching entrepreneurship education in tertiary institutions in Kwara State Nigeria.

$\mathbf{H}_{\text {02: }}$ : There is no significant difference between the mean responses of male and female business educators on the effectiveness of the strategies used for teaching entrepreneurship education in tertiary institutions in Kwara State Nigeria.

\section{METHOD OF THE STUDY}

This study adopted the survey descriptive design, and was conducted in the following tertiary institutions offering business education in Kwara State: Kwara State University, Malete, University of Ilorin, Kwara State Polytechnic, Ilorin and Kwara State College of Education Ilorin, Al-hikma University, Ilorin, Land Mark University, Grace Land Polytechnic, Offa, and Kwara State University, Lafiaji that offer business education formed the population of the study. The population of the study consists of 82 business education lecturers in the mentioned tertiary institutions in Kwara State, Nigeria as can be seen below. 
Table 1: Tertiary Institutions and number of Business Educators in Kwara State, Nigeria

\begin{tabular}{llc}
\hline S/N & Name of Institution & $\begin{array}{c}\text { Number of Business } \\
\text { Educators }\end{array}$ \\
\hline 1 & Kwara State University, Malete & 12 \\
2 & University of Ilorin, Kwara State & 08 \\
3 & Kwara Stae Polytechnic, Ilorin & 12 \\
4 & Kwara State College of Education, Ilorin & 13 \\
5 & Al-hikma University, Ilorin, Kwara State & 07 \\
6 & Land Mark University, Ilorin, Kwara State & 08 \\
7 & Grace Land Polytecnic, Offa, Kwara State & 10 \\
8 & Kwara State College of Education, Lafiaji, Kwara State & 12 \\
& Total & $\mathbf{8 2}$ \\
\hline
\end{tabular}

Source: Field survey 2018

Data for this study was collected by means of a questionnaire developed by the researcher titled "Questionnaire on identification and efficacy of strategies used in teaching entrepreneurship education in tertiary institutions in Kwara State" (IESEETI)' with four point rating scale of Strongly Agreed (SA), Agreed (A), Disagreed (D), and Strongly Disagreed (SD) for section $B$ of the questionnaire and Very High Extent (VHE), High Extent (HE), Moderate Extent (ME) and No Extent (NE) for section C. Section A of the questionnaire contains 2 items on personal data of respondents, while section B contains 20 items on identification of strategies for teaching entrepreneurship education in tertiary Institutions in Kwara State and section $\mathrm{C}$ contains another 20 items on the efficacy of the identified strategies for teaching entrepreneurship education in Kwara State tertiary Institutions Nigera. The reliability of the instrument was done using Cronbach Alpha Measure of internal consistency and the reliability co-efficient was 0.82 indicating a high reliability. The researcher administered the questionnaires with 2 research assistants within two weeks of administration. Mean rating and standard deviation were used to analyze data related to research questions while t-test statistics was used to test the two null hypotheses of the study at 0.05 level of significance. Items with mean score of 2.50 and above were considered as agreed/high extent while mean score below 2.50 were considered as disagreed/low extent. A null hypotheses was rejected when the observed p-value was less than or equal to the alpha level $(0.05)$ and retained when the observed p-value was greater than the alpha level of 0.05 . 


\section{Research Questions I}

RESULTS

What are the strategies used for teaching entrepreneurship education in tertiary institutions in Kwara State Nigeria?

Table 2: Mean and standard deviation of responses on the strategies used in teaching entrepreneurship education in tertiary institutions in Kwara State

\begin{tabular}{lllll}
\hline S/N & Strategies used for teaching entrepreneurship education & X & SD & Remark \\
\hline 1 & Use of slide and transparences on business ideas & 2.73 & 1.06 & Agreed \\
2 & Teachers' career talk on how to run small businesses & 3.46 & 0.76 & Agreed \\
3 & Film display on show of how to conduct board meetings & 2.65 & 2.70 & Agreed \\
4 & Use of marketing and distributive education in classes & 3.15 & 0.97 & Agreed \\
5 & Self-instruction on entrepreneurship & 2.96 & 1.04 & Agreed \\
6 & Use of posters to promote the teaching of entrepreneurship & 2.54 & 1.13 & Agreed \\
7 & Building of confidence into the students using pap talks & 3.42 & 0.76 & Agreed \\
8 & Giving students assignment on entrepreneurship & 3.12 & 0.86 & Agreed \\
9 & Computer programme showing business analysis & 3.31 & 1.01 & Agreed \\
10 & Formation of business clubs & 3.04 & 1.02 & Agreed \\
11 & Use of data base for developing high reasoning ability about & 3.19 & 0.96 & Agreed \\
& entrepreneurship in students & & & \\
12 & Studying of text books on business management by students & 3.12 & 0.86 & Agreed \\
13 & Use of games and simulations to show case entrepreneurship & 3.04 & 0.87 & Agreed \\
14 & Organizing competitions for students in entrepreneurship & 2.00 & 0.79 & Agreed \\
15 & Writing business plan always and presenting them before the & 3.38 & 1.0 & Agreed \\
& class & & & \\
16 & Excursions to business organizations & 2.81 & 0.89 & Agreed \\
17 & Teaching students entrepreneurship skills during lessons & 3.23 & 1.07 & Agreed \\
18 & Giving students assignment on business management always & 2.81 & 1.17 & Agreed \\
19 & Motivating students with incentives during entrepreneurship & 2.81 & 1.17 & Agreed \\
& lessons & & & \\
20 & Class discussion, always, on entrepreneurship & 3.23 & 1.15 & Agreed \\
\hline
\end{tabular}

Source: Field survey 2018

Table 1 shows the various strategies employed by lecturers in developing entrepreneurship skills in the students. The results of the analysis show that lecturers employ all the strategies except item 14, which is: organizing competitions for students on entrepreneurship. The close range of the standard deviations also shows that respondents were not very far from each other in their responses. 


\section{The Research question 2:}

How effective are the identified strategies used for teaching entrepreneurship education in Kwara State tertiary institutions Nigeria?

Table 3: Mean and standard deviation of responses on the efficacy of the strategies used for teaching entrepreneurship education

\begin{tabular}{lllll}
\hline S/N & Efficacy of the strategies used for teaching & X & SD & Remark \\
& entrepreneurship education & & & \\
\hline 1 & Use of slide and transparences on business ideas & 1.88 & 1.21 & Low Extent \\
2 & Teachers' career talk on how to run small businesses & 3.08 & 1.09 & High Extent \\
3 & Film display on show of how to conduct board meetings & 3.08 & 0.93 & High Extent \\
4 & Use of marketing and distributive education in classes & 3.23 & 1.07 & High Extent \\
5 & Self-instruction on entrepreneurship & 3.11 & 0.95 & High Extent \\
6 & Use of posters to promote the teaching of entrepreneurship & 3.12 & 0.95 & High Extent \\
7 & Building of confidence into the students using pap talks & 3.42 & 0.70 & High Extent \\
8 & Giving students assignment on entrepreneurship & 3.26 & 0.72 & High Extent \\
9 & Computer programme showing business analysis & 1.88 & 0.95 & Low Extent \\
10 & Formation of business clubs & 3.55 & 0.85 & High Extent \\
11 & Use of data base for developing high reasoning ability about & 3.12 & 1.13 & High Extent \\
& entrepreneurship in students & & & \\
12 & Studying of text books on business management by students & 3.08 & 1.13 & High Extent \\
13 & Use of games and simulations to show case & 1.98 & 0.82 & Low Extent \\
& entrepreneurship & & & \\
14 & Organizing competitions for students in entrepreneurship & 2.00 & 0.91 & Low Extent \\
15 & Writing business plan always and presenting them before & 3.23 & 1.17 & High Extent \\
& the class & & & \\
16 & Excursions to business organizations & 3.56 & 0.98 & High Extent \\
17 & Teaching students entrepreneurship skills during lessons & 3.68 & 0.94 & High Extent \\
18 & Giving students assignment on business management always & 3.02 & 0.95 & High Extent \\
19 & Class discussion, always, on entrepreneurship & 3.47 & 0.85 & High Extent \\
\hline & & & & \\
& &
\end{tabular}

\section{Source: Field survey 2018}

Table 3 presents the results of the efficacy of strategies used by lecturers in teaching of entrepreneurship education. The data analysis indicates that all the identified strategies used by lecturers are effective to high extent except items 1, 5, 6 and 15 which are effective to low extent. The analysis in Table 3 also showed that all the items are accepted as being very highly effective in teaching entrepreneurship, except items $1,5,6$, and 15 which are to low extent effective. Item 18, which is: teaching students entrepreneurship skills during lessons is the most effective strategy currently used by the lecturers involved in the teaching of entrepreneurship education as it got the highest mean of 3.68. The close range of the standard deviations indicates the homogeneity of respondents' opinions.

Ho1: $_{0}$ There is no significant difference between the mean responses of male and female business educators on the strategies used for teaching entrepreneurship education in tertiary institutions in Kwara State Nigeria. 
Table 4: Summary of t-test of the no significant difference in the mean ratings of male and female business educators regarding the identification of strategies for teaching entrepreneurship education in kwara State tertiary Institutions in Nigeria

\begin{tabular}{llllllll}
\hline Group & $\mathrm{N}$ & Mean & SD & t-cal & Df & p-value & Decision \\
\hline Male & 44 & 3.40 & 0.29 & & 80 & 0.302 & $\begin{array}{l}\text { Not } \\
\text { rejected }\end{array}$ \\
& & & & & & & \\
Female & 38 & 3.48 & 0.37 & -1.040 & & & \\
\hline
\end{tabular}

The data in Table 3 revealed that there are 44 and 38 male and female universities business educators respectively. The male had higher mean $(X=3.40 ; S . D=0.29)$ than female business educators ( $\mathrm{X}=3.48 \mathrm{SD}=0.37$ ). Their responses are close to the mean as the standard deviations are very low. The table revealed that there was no significant difference in the mean responses of the male and female business educators on the strategies for teaching entrepreneurship education $\left(\mathrm{t}_{80}=-1.040 \mathrm{p}>0.05\right)$ Therefore, the null hypothesis that there is no significance difference between the mean responses of male and female business educators on the strategies for teaching entrepreneurship education in kwara state tertiary institutions, in Nigeria was retained. Their responses though had a slight difference, with male business educators having a higher mean responses, $(X=3.40 ; S . D=0.29)$ ) but the difference was not statistically significant $($ mean difference $=0.08$ ).

Ho2: There is no significant difference between the mean responses of male and female business educators on the effectiveness of the strategies used for teaching entrepreneurship education in tertiary institutions in Kwara State Nigeria.

Table 5: Summary of t-test of the no significant difference in the mean ratings of male and female business educators on the efficacy of the identified strategies for teaching entrepreneurship education in tertiary institutions in Kwara State, Nigeria

\begin{tabular}{llllllll}
\hline Group & $\mathrm{N}$ & Mean & SD & t-cal & Df & p-value & Decision \\
\hline Male & 44 & 3.29 & 0.29 & & & & \\
& & & & & & & \\
Female & 38 & 3.27 & 0.35 & & & & \\
\hline
\end{tabular}

Source: Field survey, 2018 $\mathrm{P}>0.05$

The data in Table 5 revealed that there are 44 males and 38 female tertiary Institutions business educators respectively. The male business educators had higher mean $(X=3.29$; $S . D=0.29)$ than female business educators $(X=3.27 ; S D=0.35)$. Their responses are close to the mean as the standard deviations are very low. The table revealed that there was no significant difference in the mean responses of the male and female business educators regarding the efficacy of the identified strategies for teaching entrepreneurship education in tertiary institutions in Kwara State, Nigeria. $\left(\mathrm{t}_{80}=0.215, \mathrm{P}>0.00\right)$. Therefore, the null hypothesis that there is no significance difference between the mean responses of male and female business educators on the efficacy of the identified strategies for teaching entrepreneurship education in Kwara State tertiary institutions, Nigeria was retained. Their responses showed that male and female business educators do not differ significantly regarding the efficacy of the strategies for teaching entrepreneurship education in tertiary institutions in Kwara State, Nigeria (mean difference $=0.02$ ). Table 4 also reveals that t-calculated $(0.215)$ is less than the t-critical (1.96) at $\mathrm{P}>0.05$. We therefore fail to reject the null hypothesis of no significant difference. 


\section{DISCUSSION OF FINDINGS}

Table 1 indicates that tertiary institutions' lecturers use career talk, displaying film show on giving of assignments, asking students to study texts on entrepreneurship, excursion among others, as strategies for developing entrepreneurship among students. The outcome of this study agrees with Undiyaundeye, (2008) and Igbo, (2004), who noted that the best strategy to employ in developing the spirit of entrepreneurship in students is through the teaching of entrepreneurial skills in class rooms. The authors also agreed with the finding of the present study when they asserted that university lecturers need to adopt several strategies to achieve the implementation of entrepreneurship education in schools and colleges.

Table 2 reveals that strategies such as teaching the students entrepreneurship education in class, use of career talks, excursion to business places, film shows on successful entrepreneurship, encouraging students to interact with big time business men among other strategies were rated by respondents as very highly effective in the teaching of entrepreneurship education in tertiary institutions in kwara states. This finding is in consonance with the results of various studies of the following researchers: Jimoh-kadiri, (2012), Obikeze, (2010), Ayeduso, (2004), and Lukard (2003), who asserted that that most of the aforementioned strategies in table 2 are efficacious in the teaching of entrepreneurship education in tertiary institutions in Nigeria

The two null hypotheses of no significance difference between the opinions of male and female business educators on the strategies for teaching entrepreneurship and the efficacy of the strategies were retained at 0.05 level of significance

\section{CONCLUSION}

In conclusion, the challenge to eradicate poverty and unemployment is enormous. The population must be empowered to revitalize our weakened socio-economic pillar. The educational system in Nigeria at the tertiary level has a great part to play. Tertiary education graduates must acquire sufficient entrepreneurial skills and knowledge to become selfemployed and wealth creators and not job seekers. Tertiary institutions lecturers must be equal to the task for the sake of National development.

\section{RECOMMENDATIONS}

Based on the findings of the study, the following recommendations are made:

1. Lecturers should continue to adopt the identified strategies in the teaching and learning of entrepreneurship education, since they are highly effective in inculcating entrepreneurial skills in students

2. The recent efforts by NCCE and NUC to see that graduates of tertiary Institutions take some units in entrepreneurship education is highly commended, and should be maintained.

3. Curriculum planners should build in dynamic entrepreneurial strategies and skills into the curricular at all fields of study so as to make the curricula at every level of education be geared towards self-employment.

4. Entrepreneurship culture should be built into students by encouraging longer periods for SIWES where it obtains and monitoring the programme too, to ensure that students benefit from it. 


\section{References}

Adeyemo. S.A (2012), Class Room Interaction Pattern and Students' Learning Out comes in Senior Secondary School Physic, Journal of Educational Research and Development. Faculty of Education, Ahmadu Bello University Zaria 17(2).

Aggrarwal J.C. (2007). Essentials of Educational Technology: Innovation in Teaching and Learning. Second Edition Vikas Publication House PVT Ltd

Agnew, P. W., Kellerman A.S., \& Meyer, J. (1996). Multimedia in the Classroom. Allyn and Bacon . Boston.

Atakpa, R.A., (2011). Entrepreneurship Education: A sine qua non in Business Education Nigeria: ABEN Book of Readings

Ezenwafor, J. I., \& Ndineche G.I., (2004), Frequency of use of standard Istrucional method by Secondary schools business teachers. Business Education Journal. 4(2), 108-114

Hudson, T. (2016). Creating Learner - Centric Environments: Student Centered Learning Powered by Technology WWW. Advance-Education org./source/ student-centered learning powered technology. Retrieved on $30^{\text {th }} J u n e$, 2016.

Hisrich, R. D. \& Peters, M. P. (2002). Entrepreneurship: Fifth Edition Singapore: McGraw Hill Higher Education.

Igbo , C.A (2004) Entrepreneurship Initiative in Colleges of Education programmes paper Presented at the Workshop on Capacity Building for Lecturers in College of Education Asaba 19th $-25^{\text {Th }}$ September 2004

Igbo, C. A., (2009). Vision 2020: Challenges for Entrepreneurship in Vocational Education: Paper Delivery at a National Conference and Exhibition, Nwafor Orizu College of Education. Nsugbe, Anambra State.

Jimoh-Kadiri, S.O., (2012). Assessment of Strategies for Effective Teaching of Entrepreneurship by Business Education Teachers in Tertiary Institutions in South South Nigeria (Unpublished Doctoral Dissertation), Nnamdi Azikiwe University, Awka

National Board for Technical Education, (2007). Entrepreneurship Education for Polytechnics and similar Institutions: Training Manual 11, Kaduna: NBTE.

National Planning Commission, (2004). National Economic Empowerment and Development Strategy (NEEDS). Abuja Communication Development Incorporated.

Onyesom, M. \& Uwaifo, C.E., (2013). Reforming Entrepreneurship Education Curriculum of Nigeria Institutions for Graduate Empowerment. International Journal of Education and Research, 1(12), 141-148

Osuala, E.C., (2004). Principles and Methods of Business and Computer Education: Enugu, Cheston Agency Ltd. Osuala, E.C., (2004). Principles and Practice of Small Business Management in Nigeria. Nsukka Fullcadu company Oriazowanlan, A. O., (2013). Status of Entrepreneurship Education in South Nigeria Tertiary Institutions as perceived by Lecturers (unpublished Doctoral) Dissertation Nnamdi Azikiwe University, Awka

Uguowke, E.O (2011) Effective Utilization of ICT for Repositioning Business Education Programme in Tertiary Institution in Nigeria for National development. International Journal of Educational Research.

Vesper. K. (1980). New Venture Strategies. Eaglewood Cliff NJ (Prentice Mall). 